\title{
Breaching the Limits of Owner Occupation? Supporting Low-income Buyers in the Inflated Irish Housing Market
}

Key words: Ireland, low-income, home buyers, affordability.

Paper presented to the Home Ownership in Europe: policy and research issues conference, $23^{\text {rd }}-24^{\text {th }}$ of November 2006, Technical University Delft, the Netherlands.

\author{
by \\ Michelle Norris, \\ School of Applied Social Studies, University College Dublin, \\ Belfield, Dublin 4, Republic of Ireland. \\ T: +35317168203; E: michelle.norris@ucd.ie \\ Dermot Coates*, \\ Centre for Housing Research, Floor 2, Block 4, \\ Irish Life Centre, Dublin 1, Ireland \\ T: +3538898251; E: dcoates@ipa.ie \\ and \\ Fiona Kane*, \\ Centre for Housing Research, Floor 2, Block 4, \\ Irish Life Centre, Dublin 1, Ireland \\ T: +3538898253; E: fkane@ipa.ie
}

*: the views expressed in this paper are those of the authors and do not necessarily reflect the views of the Board or funders of the Centre for Housing Research.

Acknowledgements: we wish to acknowledge the contribution which Patrick Shiels of the Centre for

Housing Research made to collecting and preliminary analysis of the data on which this paper is

based. 


\title{
Breaching the Limits of Owner Occupation? Supporting Low-income Buyers in the Inflated Irish Housing Market
}

\author{
In the Republic of Ireland broadly targeted, generous and longstanding state subsidisation of home \\ purchase has resulted in relatively high rates of home ownership compared to the rest of Western \\ Europe. During the 1980s however, several of these generalist subsidies were abolished and the \\ remainder reoriented towards enabling low income households to purchase a home, while the last ten \\ years have seen unprecedented house price inflation. This paper which examines the operation of \\ these low-income home buyer supports in five case study areas reaches largely negative conclusions \\ about their efficacy in the current housing market context. These measures have failed to stem the \\ recent fall in the proportion of Irish households that own their homes. Despite efforts to increase \\ transactions by introducing new schemes of this type, levels of use have remained static since the early \\ 1990s. More seriously widespread arrears on mortgages held by scheme participants casts doubts \\ on the sustainability of the home ownership they facilitate. Thus, the Irish case demonstrates that \\ even when heavily subsidised home ownership does have natural limits and highlights the problems \\ associated with attempting to breech these limits by lifting low-income households into this tenure.
}

Levels of home ownership in the Republic of Ireland are relatively high compared to many other western European countries. 77.4 per cent of Irish households own their own homes compared to an average of 63.8 per cent in the fifteen countries that were European Union members prior to 2004 (Norris and Shiels, 2004). Home ownership rates are obviously related to a range of economic, demographic and cultural factors, however in the Irish context they are also the result of longstanding government support for this tenure (O’Connell, 2005). This support can be traced back to the Small Dwellings Acquisitions Act, 1899, which enabled local authorities to provide loans for home purchase. Following the foundation of the Irish State in 1922 a number of other supports for owner occupiers were introduced, including: grants for first time buyers (introduced in the 1920s), 
the tenant purchase scheme which enables social renting tenants of local authorities to buy their dwelling (made available in rural areas from the mid 1930s and extended to urban areas from the 1960s) and tax relief on mortgage interest (Norris and Winston, 2004).

The last two decades have seen radical changes in both home ownership policy and in the socioeconomic context for policy making in this area. From the mid 1980s to the early 1990s, the scale of universal supports for home buyers was rolled back. Some of these measures, such as the first time buyer's grant, were abolished, while others were re-orientated towards supporting low-income buyers specifically, as for instance, access to local authority housing loans was limited to low-income households that had failed to gain finance from commercial lenders (Fahey and Maitre, 2004). In addition several new supports for low-income home buyers, such as the shared ownership and mortgage allowance schemes, were introduced at this time (Norris and Winston, 2004). From the mid 1990s strong economic and population growth, coupled with falling average household size and interest rates, led to a marked increase in the demand for housing (Central Statistics Office, 2003: Fahey et al, 2004). As a result, the traditional pattern of low and steady residential property price inflation ceased. House price inflation increased from 7.7 per cent per annum between 1990 and 1993, to 22 per cent per annum between 1996 and 2002 and private rent inflation jumped from 3 per cent per annum between 1990 and 1996 to 14.6 per cent in 2000/2001. Ensuing concerns about the affordability of home purchase for low-income households inspired the introduction of further measures to enable this group to access the housing market, most notably the affordable housing scheme which was established in 1999 (Norris and Winston, 2004).

This paper examines the effectiveness of the main low-income home buyer supports (hereafter: LIHBS) in the light of these housing market developments. It draws on management data collated by five of the local authorities that administer these measures, which encompasses 14,961 households or 28.6 per cent all of the participants in these schemes between 1990 and 2003, together with in- 
depth interviews with policy makers and local authority managers working in this area. This analysis is presented in six sections. The next section describes the research methods employed to assemble these data and outlines the terms of the LIHBS examined here. This is followed by an analysis of: the numbers of participants in these schemes; the characteristics of participant households; their incomes and the prices of their dwellings and the affordability of this method of accessing home ownership. The conclusions to the paper examine the housing policy issues arising from the preceding discussion.

\section{Data and Focus}

This paper examines the most significant supports for low-income home buyers in operation in Ireland during the 1990s, namely: the tenant purchase, shared ownership, local authority housing loan, mortgage allowance and affordable housing schemes. Full details of the focus of these schemes and the main amendments made to their terms since 1990 are set out in Table 1 . Two further consequential LIHBS have been established in recent years - the provision of housing for sale at below market value via the planning system (legislated for in the Planning and Development Act, 2000) and on state owned lands (the Affordable Housing Initiative) (see: Norris, 2006 and Government of Ireland, 2003). However because very few households had availed of these initiatives at the time of data collection, they were excluded from this analysis.

Table 1 here. 
The paper examines the operation of these schemes in five local authority operational areas: Dublin City Council and Leitrim, Longford, South Dublin and Wicklow County Councils. These areas, which are distributed across the East and Midland regions, were chosen in order to encompass a mix of urban and rural areas, which reflects the distribution of the Irish population at large (60 per cent urban/ 40 per cent rural). Dublin City and South Dublin County Council are urban in character, while the other three areas are predominately rural.

Two research methods were employed to operationalise this research. Firstly 15 in-depth interviews were conducted with the staff responsible for administering these schemes in the various local authorities under examination. This aspect of the research explored interviewees' experience of implementing these schemes and views on their benefits and shortcomings. Secondly, management information was collected on the personal characteristics, finances, repayment histories and housing careers of 14,961 households in these five case study areas that availed of these schemes between 1990 and 2003. These data encompass 100 per cent of LIHBS participants in all of the case study areas with the exception of Dublin City Council. In this case data on only 40 per cent of participants in the tenant purchase scheme could be accessed. However these data encompass an even spread of participants in each year between 1990 and 2003 so they do not skew the dataset significantly.

\section{Claimant Numbers}

Figure 1 details nationwide trends in LIHBS participants between 1990 and 2003. It highlights the substantial contribution of the tenant purchase scheme to the total transactions under these supports - it accounted for 52.3 per cent of LIHBS transactions between these years. In contrast the shared 
ownership and local authority loans schemes made up 27.2 per cent and 10.9 per cent of transactions respectively, but the relative contribution of the affordable housing and mortgage allowance schemes is much smaller (5.5 and 4.1 per cent respectively).

Figure 1 here.

Figure 1 also reveals distinctive patterns in the number of transactions under each of these schemes during the period under examination. Sales under the tenant purchase scheme fell dramatically between 1990 and 1994, although they have recovered since then they remain substantially below their 1990 level and a fraction of sales levels in preceding decades (Norris, 2005). Similarly use of local authority loans to buy dwellings on the open market (i.e. not in conjunction with other LIHBS) fell by almost 700 per cent between 1991 and 2003. Since their establishment in 1991, shared ownership transactions have fluctuated between 1,000 and 1,500 per annum and mortgage allowance transactions have remained stubbornly low at less than 200 annually. Whereas sales of affordable housing have increased significantly since its initiation in 1999. These trends in LIHBS transactions are related to both the terms of these schemes and other structural factors connected to broader socio-economic and housing market developments.

The latter factor is particularly pertinent to use of the tenant purchase and to a lesser extent the mortgage allowance scheme. Although there are no income limits for access to either of these schemes, access is limited to local authority tenants and take up has been impeded by the residualisation of this tenure - in 200062.2 per cent of local authority tenants had incomes below 60 per cent of median compared to 22.1 per cent of all households - which has decreased the affordability of home purchase and impeded access to mortgage credit (Fahey et al, 2004). In addition, the potential for sales under this scheme has been curtailed by the exclusion of local authority flats and tenants of social housing provided by voluntary and co-operative housing 
associations (which provide approximately ten per cent of social housing in Ireland) from the right to buy. There is no doubt that strong house price inflation during the last decade which has risen much faster than average incomes has also impeded take up of all of the LIHBS under examination here. However, the lack of income limits for access to the mortgage allowance and tenant purchase scheme indicates that this factor has been particularly influential in these cases. This conclusion was supported by the local authority officials interviewed for this study who argued that, despite the large discounts available to tenant purchasers, strong house price inflation associated with the gentrification of many local authority estates where sales to tenants have traditionally been high has impeded the remaining tenants' ability to avail of this option.

Figure 2 also examines the impact of two aspects of the terms of the LIHBS on transaction levels. The data presented here indicates that the falling use most of these schemes since 1990 is strongly related to the failure of the income limits for access to keep pace with rising incomes, which has reduced the number of eligible households. Whereas other more minor changes to their qualification criteria has had little impact on usage rates. For instance the reduction in the initial minimum equity which shared owners are obliged to purchase in 1995, failed to stem the fall in the use of the scheme over the three subsequent years. Whereas the marked increases in the income limits for access to this scheme in 1999 and 2000 did effect a subsequent rise in transactions. Figure 2 also indicates that the failure of the maximum local authority loans available to keep pace with house price inflation may have impacted negatively on the use of this measure and of the other LIBHS, because participants reliant on this source of funding were priced out of the housing market. Those buying in the higher price locations of Dublin City and South Dublin County Councils are likely to have been particularly negatively effected in this regard as are shared ownership and affordable housing scheme participants as they were solely reliant on this source of finance between 1990 and 2003. Whereas, the option of using either private or local authority mortgage finance has been available to mortgage allowance participants since 1991 and to tenant purchasers since 1995. 
Figure 2 here.

Interviews with the local authority officials responsible for administering these supports also identified a number of additional aspects of their design which have reduced their popularity. In their view the terms of the shared ownership scheme are overly complex. In particular the arrangement whereby participants pay both a mortgage on their portion of the equity and rent on the local authority's share is difficult to understand. Conversely interviewees cited the relative simplicity of the affordable housing scheme as one of the factors that has inspired its steady growth in popularity since its establishment in 1999. Low take up of the mortgage allowance scheme was also linked to the relatively small level of the allowance in comparison to the discounts available to tenant purchasers. Although it is worth noting that this strategy was deliberate on the part of government which was anxious to avoid the 'large scale surrender of local authority houses' as took place between 1985 and 1987 when a more generous version of the mortgage allowance scheme was made available (Department of the Environment, 1991: p. 23). This exodus destabilised community structures in many local authority estates and because the tenants who took advantage of the grant generally had relatively high incomes also undermined the local economy (Threshold, 1987). Declining use of local authority loans is related to the liberalisation and growth of the commercial mortgage sector in recent years which has eased access to this source of finance and to the removal of the stipulation that tenant purchasers must employ local authority loans in 1995. Finally, the local authority officials interviewed for this study unanimously attributed the sharp fall in tenant purchase transactions in the early 1990s to the impact of 'once off' additional discount made available on transactions made in 1988 and 1989 (O'Connell, 2005). The volume of transactions in these years was so high that some applicants were not processed until the early 1990s and are included in the transactions for these years detailed in Figure 1. 


\section{Clientele}

Table 2 examines the characteristics of LIHBS participants in the case study local authority areas in 1992/1993 and 2002/2003. These data reveal that the characteristics of participants changed significantly during the period under review, as:

- the proportion of female-headed (defined as the primary applicant on application forms) participant households increased significantly

- the proportion of participant households headed by a never married person increased,

- as did the proportion of participant households without children.

These developments reflect changes in the characteristics of the Irish population at large. The proportion of all Irish homebuyers who were married when they bought their home fell by 48.2 per cent between 1992/93 and 2002/03 (Department of the Environment, Heritage and Local Government, various years). While the proportion of Irish households without children grew by six per cent in the eleven years to 2002 (Central Statistics Office, 2003).

However despite these changes, the characteristics of LIHBS participants remains atypical compared to the general Irish population and participants in certain schemes are particularly distinctive in this regard. Thus LIHBS participants in general, but particularly participants in the tenant purchase and mortgage allowance schemes, are more likely to be married compared to home buyers in general only 7.6 per cent of all the households that drew down new mortgages in 2000/03 were married (Department of the Environment, Heritage and Local Government, various years). LIHBS participants are also significantly less likely to have children than the population at large (in 2002 25.19 per cent of all Irish households contained no children). In addition the average size of LIHBS participant households is smaller than the national norm. In 200223.1 of Irish households contained 
three or more children compared to just 12.3 per cent of LIHBS participants (Central Statistics Office 2003).

\section{Incomes and Prices}

Figure 3 compares trends in the weekly gross household incomes of LIHBS participants to all households in the state. As would be expected considering that these supports specifically target low income households it reveals that participant's incomes are significantly lower than the national average. The latter stood at $€ 868.12$ per week in 2002 , whereas the equivalent figure for LIHBS participants was only €498.18. Among LIHBS participants, recipients of local authority loans enjoyed the highest household incomes (€556.25) whereas the incomes of participants in the mortgage allowance and tenant purchase schemes were lowest ( $€ 479.57$ and $€ 436.45$ respectively). This specific trend reflects the acute residualisation of the local authority rented tenure mentioned above (Fahey et al, 2004). Whereas the relatively low incomes of participants in the means tested LIHBS (shared ownership, affordable housing and local authority loans) reflects the failure of the income limits for access to keep pace with rising average incomes. More broadly however the growing divergence between the incomes of LIHBS participants and the population at large reflects growing income inequality during Ireland's economic boom, as income growth was concentrated among households in the top 60 per cent of the income spectrum (Cantillon, 2005).

Figure 3 here. 
More detailed analysis reveals marked differences between the household incomes of LIHBS participants resident in urban and rural areas. In 2002/2003 the incomes of participants resident in Dublin City Council and South Dublin County Council operational areas was 17.8 per cent higher than their rural counterparts. These differences are particularly marked among participants in tenant purchase and mortgage allowance schemes, whereas the difference between urban and rural participants in the means tested LIHBS is small.

Figure 4 compares trends in the price of dwellings bought using the LIBHS between 1990 and 2003 with general housing market trends. In the case of dwellings bought using the affordable housing and tenant purchase scheme the prices detailed here reflects the discounts enjoyed by participants rather than the market value - which in 2002/2003 averaged 31.6 per cent and 22.2 per cent respectively. Not surprisingly therefore, Figure 4 indicates that the cost of dwellings purchased via these schemes was consistently lower than dwellings bought using the shared ownership, local authority loans and mortgage allowance schemes which were sold for their market value (although shared ownership scheme participants did not purchase the entire equity in the dwelling initially). However the mean price of dwellings purchased using all of the five LIHBS under examination was significantly less than house prices in general.

Figure 4 here.

Figure 4 also reveals between 1992 and 2003, the average price paid by participants in all the five LIHBS increased by 394.5 per cent, whereas the price of all dwellings increased by just 263.8 per cent during the same period. Higher house price inflation among LIHBS dwellings reflects the particularly large proportion (80 per cent) of the households examined in this study that are resident in the relatively high cost locations of Dublin City and South Dublin County Councils. Between 1990 and 2003 scheme participants living in these urban areas paid 49.6 per cent more for their 
dwellings than their rural counterparts and prices in these urban areas rose by 424 per cent during this period compared to 227 per cent in rural areas. As was alluded to earlier, the scheme administrators interviewed also linked this phenomenon to higher price inflation at the bottom end of the housing market. This view is supported by the limited amount of relevant data available such as the Economic and Social Research Institute's (various years) survey of mortgages issued by one building society which indicates between 2000 and 2006 that the average house price paid by first time buyers increased by 11.5 per cent more than that paid by existing home owners.

\section{Affordability}

In order to assess the implications of these trends in house prices and incomes for the affordability of home purchase by LIHBS participants, Figure 5 compares the average incomes of participant households to the prices of the dwellings they purchased. These data reveal that in the early 1990s, with the exception of the shared ownership scheme, the ratio of house prices to incomes was lower among LIHBS participants than among the population at large. In 1992, this ratio ranged from a low of 1.51 among tenant purchasers to a high of 2.29 among local authority loan recipients compared to 4.1 for all households in the State. As a result of strong house price inflation the house price to income ratio for the population at large rose to 5.42 by 2003 . However the equivalent ratios for participants in the LIHBS rose even more. By 2003 most participants in the tenant purchase, mortgage allowance and local authority loan schemes bought properties which cost between four and five times their income. According to Figure 5, the house price to income ratios for shared ownership participants was significantly higher than is the case for the other LIHBS. However, these data are somewhat misleading since shared owners only buy a portion of the equity initially (on 
average 52 per cent among households in the case study areas) and rent the remainder from the local authority.

Figure 5 bere.

In order to overcome this discrepancy Table 3 examines the proportion of LIHBS participants that devoted 35 per cent or more of their gross weekly income to mortgage and rent payments. This measure reflects the de facto official definition of housing unaffordability, proffered in the Planning and Development Act 2000, which is used by local authorities to assess the need for housing for sale at below market value (although this definition refers to net income, only gross income data were available for this analysis) (Norris, 2006). These data reveal that on average one-third all LIHBS participants devoted more than 35 per cent of their gross incomes to housing costs, but this rises to 51.8 per cent among shared owners. Disaggregating the latter figure reveals that, on average, 21 per cent of gross income was used to service the loan on buyers' share of the equity in the dwelling and only 1.9 per cent of participants devoted in excess of 35 per cent of gross weekly income to mortgage payments alone. However when the rent levied on the local authority's share of the dwelling is included relative expenditure increases dramatically.

Table 3 here.

Mortgage arrears are also an important indicator of housing unaffordability and the available data on the extent of this problem among LIHBS participants is also set out in Table 3. These data only encompass participants who use local authority loan finance to purchase a dwelling on the open market or using the affordable housing, shared ownership or tenant purchase scheme. Nevertheless this includes all of the shared ownership and affordable housing scheme participants and all tenant purchasers who bought their dwelling prior to 1995 and approximately one third of such households 
since then, so these data are reasonably comprehensive. Moreover, the very high levels of arrears highlighted in this table, particularly among shared owners and tenant purchasers and urban LIHBS participants in general clearly indicates that there is a significant problem in this regard. This view is also supported by the other research on loan arrears among this group (Downey, 1998; Department of the Environment and Local Government, 1997). Whereas research by the Irish Mortgage and Savings Association (2001) found that only 7.2 per cent of all commercial mortgage borrowers in Ireland were in arrears in 2001.

\section{Conclusions}

Broadly targeted, generous and longstanding state subsidisation of home purchase has resulted in relatively high rates of home ownership rates in Ireland compared to the rest of Western Europe (O'Connell, 2005). During the 1980s however, several of these generalist subsidies were abolished and the remainder reoriented towards enabling low income households to purchase a home, while the last ten years has seen unprecedented house price inflation. The evidence presented in this paper on the operation of these low income home buyer supports in five case study areas points to largely negative conclusions about their efficacy in the current housing market context at least.

Although the five LIHBS examined here enabled 41,208 households to buy a dwelling between 1991 and 2002, which constitutes 29 per cent of the additional households that accessed this tenure during this period, they failed to stem the concurrent 2.8 per cent fall in the proportion of Irish households that own their homes - the highest such decline in the history of the State (Central Statistics Office, 2004). Despite government efforts to increase LIHBS transaction rates by introducing new schemes 
of this type, levels of use have remained static since the early 1990s. More seriously, widespread arrears on the mortgages held by LIHBS participants casts doubts on the sustainability of the home ownership facilitated by these schemes.

Static LIHBS transactions are linked to the complexity of these schemes and also to the failure of government to update the maximum incomes required for access to reflect rising average incomes and house prices and also to structural factors - namely the residualisation of the local authority rented sector which is the main source of participants in the non means tested LIHBS and more broadly to rising house prices and income inequality during Ireland's economic boom. These structural factors indicate that a significant increase in the income limits for access will be required to increase LIBHS transactions. Indeed, if Ireland's housing market continues to boom, such a reform will probably be necessary to prevent further decline in home ownership levels. In any case the extent of mortgage arrears among existing LIHBS participants indicates that a significant proportion of the cohort currently targeted by these measures would be more appropriately accommodated in social or private rented housing, at least until their household incomes rise and/or their outgoings decline. Ford et al's (2001) research in the United Kingdom links risk of mortgage arrears and repossessions to low incomes, insecure employment, changing family structures particularly increased marital breakdown and high outgoings associated with larger family size. The data on which this paper is based reveals higher marriage rates and lower numbers of children among LIHBS participants compared to the Irish population at large. This indicates that mortgage arrears among the former are principally the result of their low incomes and the relatively large proportion of income devoted to housing costs, which breech the statutory affordability criteria in a substantial proportion of cases.

In the last two decades governments in most Western European countries have instituted policies to increase home ownership rates, in several cases as part of a drive to enable 'asset based welfare', in 
other words to promote the acquisition of assets such as dwellings, on the understanding that these will be liquidated to pay for social or medical care if necessary, thus relieving the state of its responsibilities in this regard (Norris and Shields, 2004: Malpass, 2005). The Irish case casts doubts on the viability of this strategy. It indicates that when heavily subsidised home ownership does have natural limits and highlights the problems associated with efforts to breech these limits by attempting to lift households with very low incomes into this tenure. 


\section{References}

Cantillon, S (2005), 'Equality in Economic and Other Dimensions', in O'Hagan, J and Newman, C (Eds), The Economy of Ireland, National and Sectoral Policy Issues pp. 106-154, Dublin, Gill and Macmillan.

Central Statistics Office (2003), Census 2002 - Principal Demographic Results, Dublin, Stationery Office.

Central Statistics Office (2004), Census 2004: Volume 13, Housing, Dublin, Stationery Office.

Central Statistics Office (various years), Statistical Yearbook of Ireland, Dublin, Central Statistics Office.

Department of the Environment (1991) A Plan for Social Housing, Dublin, Stationery Office.

Department of the Environment and Local Government (1997); Value for Money Unit Report No. 18: Comparative Data on Local Authority Revenue Collection Accounts, Dublin, Department of the Environment and Local Government.

Department of the Environment, Heritage and Local Government (various years), Annual Housing Statistics Bulletin, Dublin, Department of the Environment, Heritage and Local Government.

Downey, D. (1998); New Realities in Irish Housing: a study on housing affordability and the economy, Dublin, CRUBE/Threshold.

Economic and Social Research Institute (various years), ESRI/ Permanent TBS House Price Index, Dublin, Economic and Social Research Institute.

Fahey, T and Maitre, B (2004), 'Home Ownership and Social Inequality in Ireland', in, Kurz and Blossfeld, H (eds.), Home Ownership and Social Inequality in Comparative Perspective, pp. 281-303, Stanford, Stanford University Press)

Fahey, T., Nolan, B. and Maitre, B. (2004); Housing, Poverty and Wealth in Ireland, Dublin, Combat Poverty Agency.

Ford, J, Burrows, R and Nettleton, S (2001), Home Ownership in a Risk Society: A Social Analysis of Mortgage Arrears and Possessions, Bristol, Policy Press).

Government of Ireland (2003), Sustaining Progress: Social Partnership Agreement, 2003-2005, Dublin: Stationery Office.

Irish Mortgage and Savings Association (2002); Annual Review 2001-2002, Dublin: Irish Mortgage and Savings Association.

Malpass, P (2005), Housing and the Welfare State: the development of housing policy in Britain, London: Palgrave.

Norris, M (2005), 'Social Housing', in, Norris, M and Redmond, D (Eds), Housing Contemporary Ireland: Policy, Society and Shelter, pp.160-183, Dublin, Institute of Public Administration).

Norris, M (2006), 'Developing, Designing and Managing Mixed Tenure Housing Estates: Implementing planning gain legislation in the Republic of Ireland' in European Planning Studies, 14(2), pp. 199-218.

Norris, M and Shiels P (2004), Regular National Report on Housing Developments in European Countries: synthesis report, Dublin, Stationery Office.

Norris, M. and Winston, N. (2004) Housing Policy Review 1990-2002, Dublin, Stationery Office.

O'Connell, C (2005), 'The Housing Market and Owner Occupation in Ireland', in Norris, M and Redmond, D (Eds), Housing Contemporary Ireland: Policy, Society and Shelter, pp. 21-43, Dublin, Institute of Public Administration. 
Threshold, (1987), Policy Consequences: A Study of the f,5000 Surrender Grant in the Dublin Housing Area, Dublin, Threshold. 
Table 1: Terms of and Reforms to Low Income Home Buyer Supports, 1990-2003

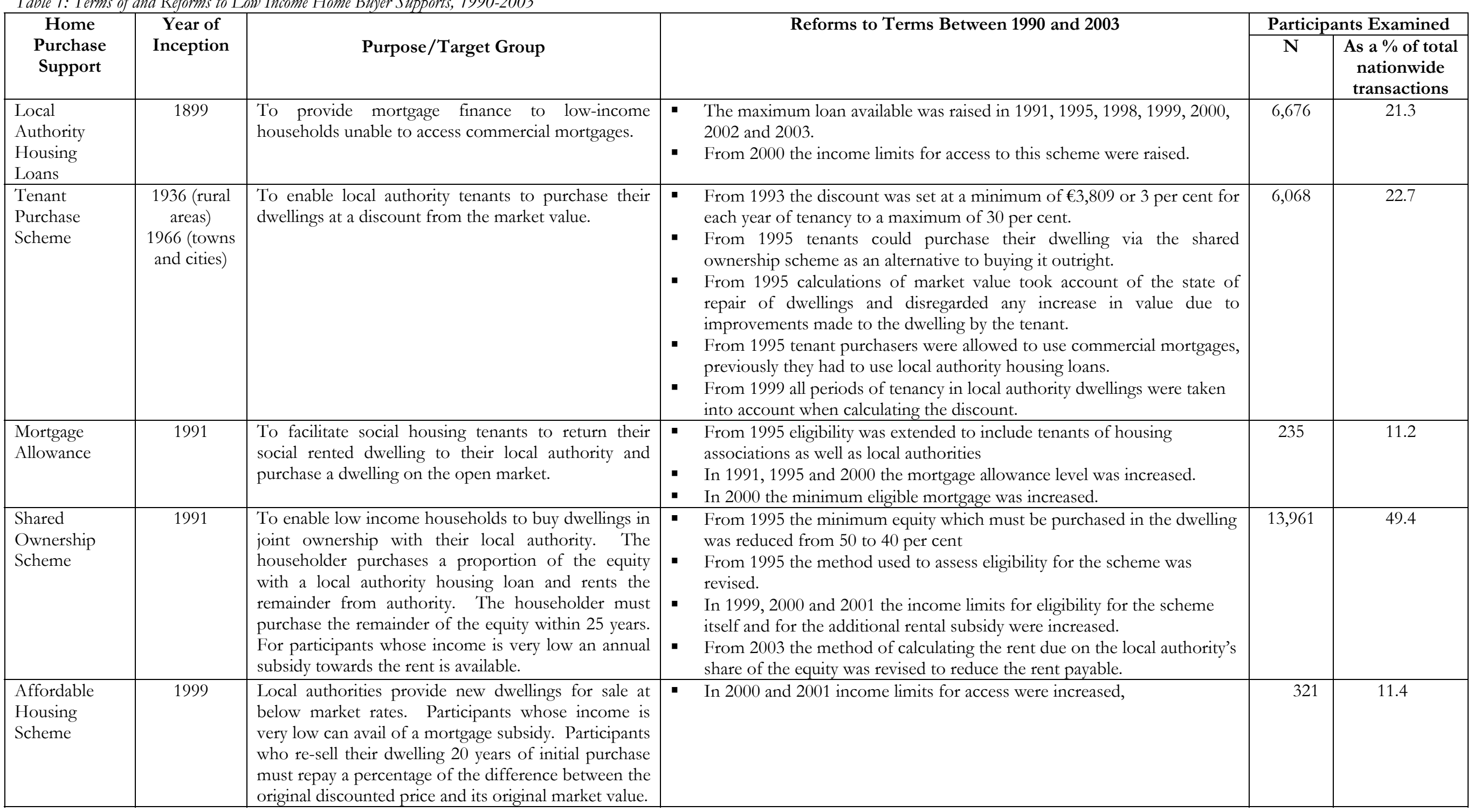




\begin{tabular}{|c|c|c|c|c|c|c|c|c|c|c|c|c|}
\hline \multirow[t]{3}{*}{ Scheme } & \multirow{2}{*}{\multicolumn{2}{|c|}{ \% Female beaded }} & \multirow{2}{*}{\multicolumn{2}{|c|}{$\begin{array}{l}\% \text { Household heads } \\
\text { married }\end{array}$}} & \multirow{2}{*}{\multicolumn{2}{|c|}{$\begin{array}{l}\text { \% Household beads } \\
\text { never married }\end{array}$}} & \multicolumn{6}{|c|}{ Children } \\
\hline & & & & & & & \multicolumn{2}{|c|}{$\%$ with no children } & \multicolumn{2}{|c|}{$\%$ with 1-2 children } & \multicolumn{2}{|c|}{$\begin{array}{l}\% \text { with } 3 \text { or more } \\
\text { children }\end{array}$} \\
\hline & $92 / 93$ & $02 / 03$ & $92 / 93$ & $02 / 03$ & $92 / 93$ & $02 / 03$ & $92 / 93$ & $02 / 03$ & $92 / 93$ & $02 / 03$ & $93 / 93$ & $02 / 03$ \\
\hline $\begin{array}{l}\text { Tenant } \\
\text { Purchase }\end{array}$ & 35.8 & 50.9 & 76.6 & 64.2 & 2.4 & 20.4 & 5.7 & 30.1 & 32.2 & 44.5 & 62.1 & 14.4 \\
\hline $\begin{array}{l}\text { Mortgage } \\
\text { Allowance }\end{array}$ & 20.7 & 67.7 & $\mathrm{Nav}$ & $\mathrm{Nav}$ & $\mathrm{Nav}$ & $\mathrm{Nav}$ & 31.8 & 4.2 & 54.6 & 58.3 & 13.6 & 37.5 \\
\hline $\begin{array}{l}\text { Local Authority } \\
\text { Loan }\end{array}$ & 22.2 & 46 & 43.8 & 20.6 & 34.8 & 50 & 46.9 & 56.9 & 43.8 & 40.6 & 9.3 & 2.5 \\
\hline $\begin{array}{l}\text { Shared } \\
\text { Ownership }\end{array}$ & 38 & 46 & 53.3 & 10 & 27.2 & 79.4 & 31.9 & 66.9 & 60.2 & 31 & 7.9 & 2.1 \\
\hline $\begin{array}{l}\text { Affordable } \\
\text { Housing }\end{array}$ & $\mathrm{N} / \mathrm{a}$ & 46 & $\mathrm{~N} / \mathrm{a}$ & 15.6 & $\mathrm{~N} / \mathrm{a}$ & 54.4 & $\mathrm{~N} / \mathrm{a}$ & 60 & $\mathrm{~N} / \mathrm{a}$ & 34.8 & $\mathrm{~N} / \mathrm{a}$ & 5.2 \\
\hline Mean & 29.2 & 51.3 & 43.4 & 27.6 & 21.5 & 51.1 & 29.1 & 43.6 & 47.7 & 41.8 & 23.2 & 12.3 \\
\hline
\end{tabular}

Source: administrative data generated by Dublin City Council and Longford, Leitrim, South Dublin and Wicklow County Councils.

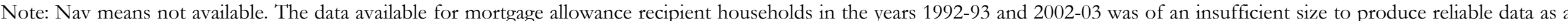

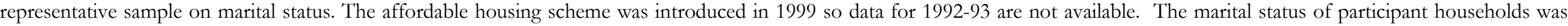

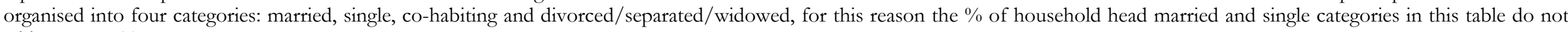
add up to $100 \%$. 
Table 3 Households Spending More than 35 Per cent of Gross Weekly Income on Rent or Mortgage Payments and Local Authority Housing Loan Arrears Among Participants in the Low Income Home Buyer Supports, 1990-2003

\begin{tabular}{|l|c|c|c|}
\hline Scheme & $\begin{array}{c}\text { \% of households spending } \\
\text { 35 per cent or more of gross } \\
\text { weekly income on rent or } \\
\text { mortgage payments }\end{array}$ & \multicolumn{2}{|c|}{$\begin{array}{c}\text { \% of households in arrears of } 3 \text { months } \\
\text { or more duration }\end{array}$} \\
\cline { 3 - 4 } & 32.9 & Rural Areas & Urban Areas \\
\hline Tenant Purchase & 33.3 & 21.2 & 44.4 \\
\hline Mortgage Allowance & 40.2 & 23.1 & Nav \\
\hline Local Authority Loan & 51.8 & 40.8 & Nav \\
\hline Shared Ownership & 33.0 & 25.7 & 35.1 \\
\hline Affordable Housing & & & $44.4^{*}$ \\
\hline
\end{tabular}

Source: administrative data generated by Dublin City Council and Longford, Leitrim, South Dublin and Wicklow County Councils.

Note: In the case of the shared ownership scheme the data on the \% of households spending more than 35 per cent of gross weekly income on housing costs data assume that households have used a local authority loan to purchase their dwelling and own 52 per cent of its equity. * refers to arrears of any duration. Rural areas refer to Leitrim, Longford and Wicklow County Council, urban areas refer to Dublin City and South Dublin County Councils. Data for local authority loans refers to loans used to purchase dwellings on the open market only and not in tandem with any other LIHBS. Data on mortgage arrears for the affordable housing scheme in rural areas refer to 2002 and 2003 only. Data for the tenant purchase scheme in urban areas refer to South Dublin County Council only. Data for the shared ownership and affordable housing schemes in urban areas refer to Dublin City Council only. Data for the mortgage allowance scheme are not available. 


\section{Figures}

Figure 1 Low Income Home Buyer Support Scheme Transactions, 1990 - 2003

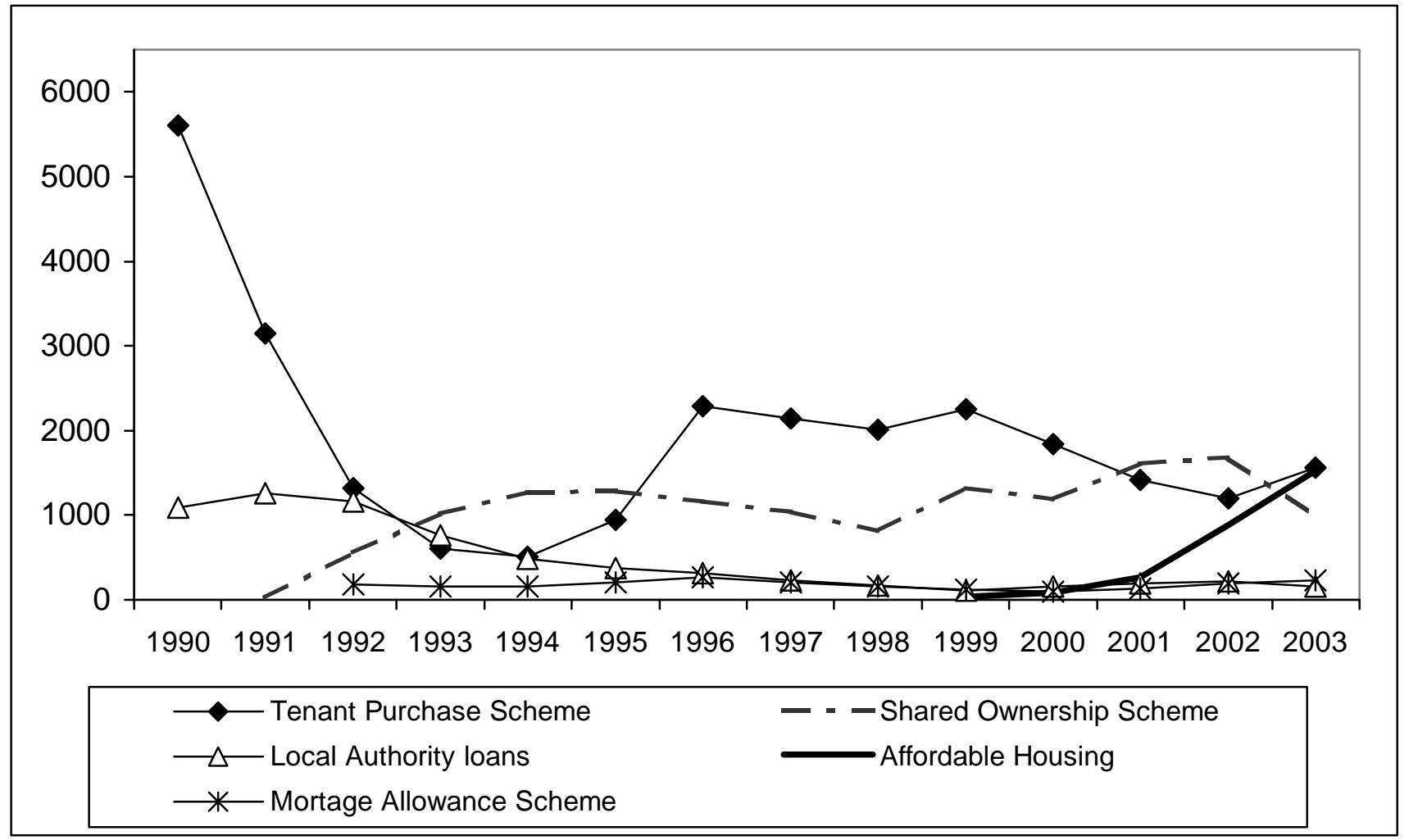

Source: Department of the Environment, Heritage and Local Government (various years).

Note: Data on local authority loans refers to loans advanced for the purchase of dwellings on the open market and not loans used in conjunction with other home purchase supports examined here. 
Figure 2 Single Person Households' Income Limits for Access to the Shared Ownership, Local Authority Housing Loan and Affordable Housing Schemes as a \% of Average Industrial Earnings and Local Authority Housing Loan Maxima as a of Average House Prices, 1990 - 2003

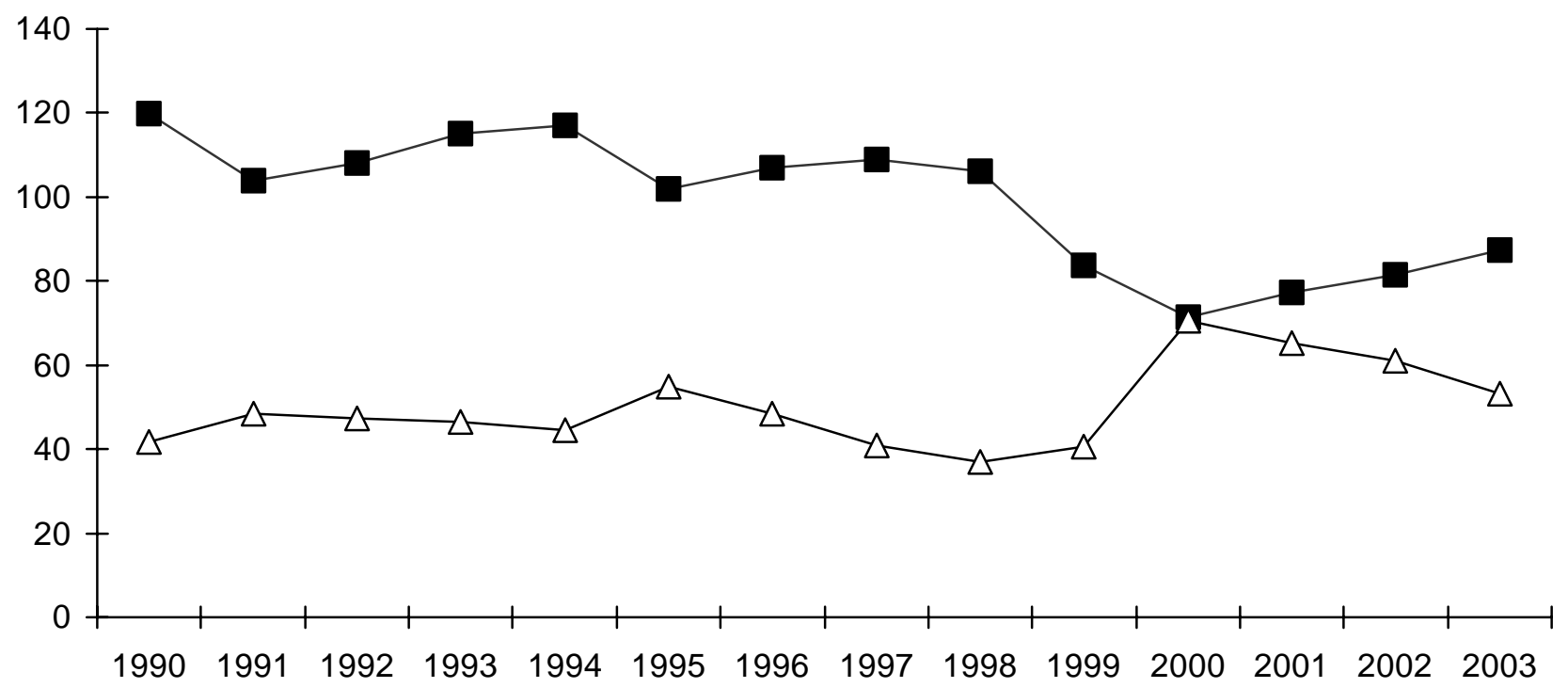

- Single Person's Income Limits for Access to Shared Ownership, Local Authority Housing Loans and Affordable Housing Scheme as \% of Average Industrial Earnings

$\neg$ Maximum Local Authority Housing Loan as a \% of Average House Prices

Source: Department of the Environment, Heritage and Local Government (various years) and administrative data generated by Dublin City Council and Leitrim, Longford, South Dublin and Wicklow County Councils.

Note: only the local authority housing loan scheme was operational for the full period examined in this graph, the shared ownership scheme was founded in 1991 and the affordable housing scheme was founded in 1999. Average house prices refer to the mean of new and second hand house prices. 
Figure 3 Change in Gross Mean Weekly Household Income of Participants in the Low-income Home Buyer Support Schemes and all Households, 1990 to 2003

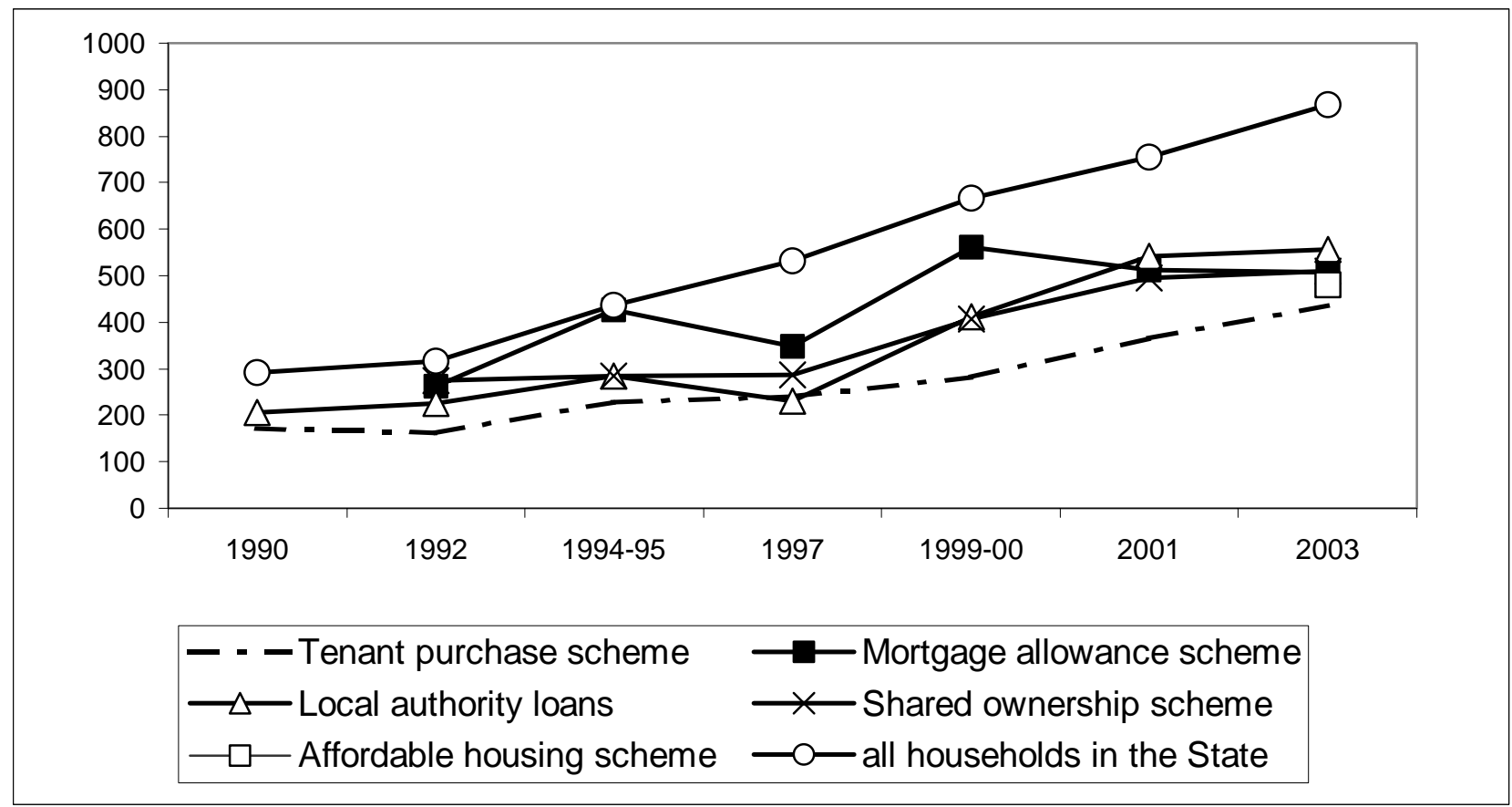

Source: Central Statistics Office (various years) and administrative data generated by Dublin City Council and Leitrim, Longford, South Dublin and Wicklow County Councils.

Note: data for all households is abstracted from a number of sources: 1990 and 1992 data is taken from Index of Average Industrial Earnings; 1994-95 and 1999-00 data is taken from Household Budget Survey; 1997, and 2001 data is taken fro ESRI Living in Ireland Survey. 2003 data taken from the EU Survey on Income and Living Conditions 2004. Income data does not account for income tax, social insurance or pension related deductions nor does it measure welfare related inputs. 
Figure 4 Change in Average House Prices for Dwellings Acquired Using Low Income Home Purchase Supports and all Dwellings, 1990 to 2003

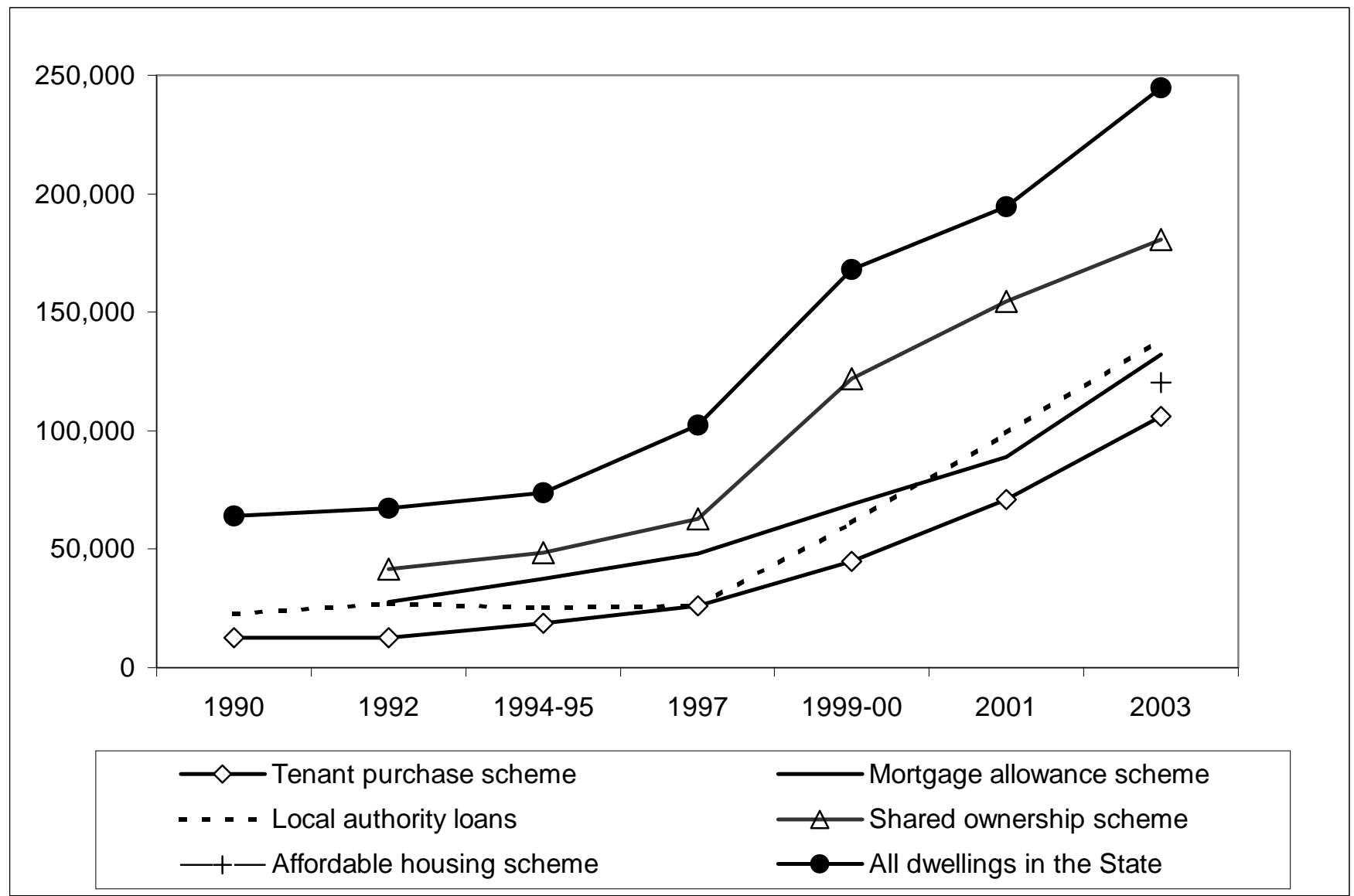

Source: administrative data generated by Dublin City Council and Leitrim, Longford, South Dublin and Wicklow County Councils and Department of the Environment, Heritage and Local Government (various years).

Note: Data on the tenant purchase and affordable housing schemes refer to the discounted price paid by purchasers; data on the mortgage allowance and local authority loan schemes refer to the value of mortgages. Participants in the shared ownership scheme do not initially purchase all of the equity in their dwellings, in the five case study areas these households initially purchased 52 per cent of the value of their dwelling between 1991 and 2003 on average. 
Figure 5. House Price to Income Ratio of Participants in the Low-income Home Purchase Support Schemes and all Households, 1990 to 2003.

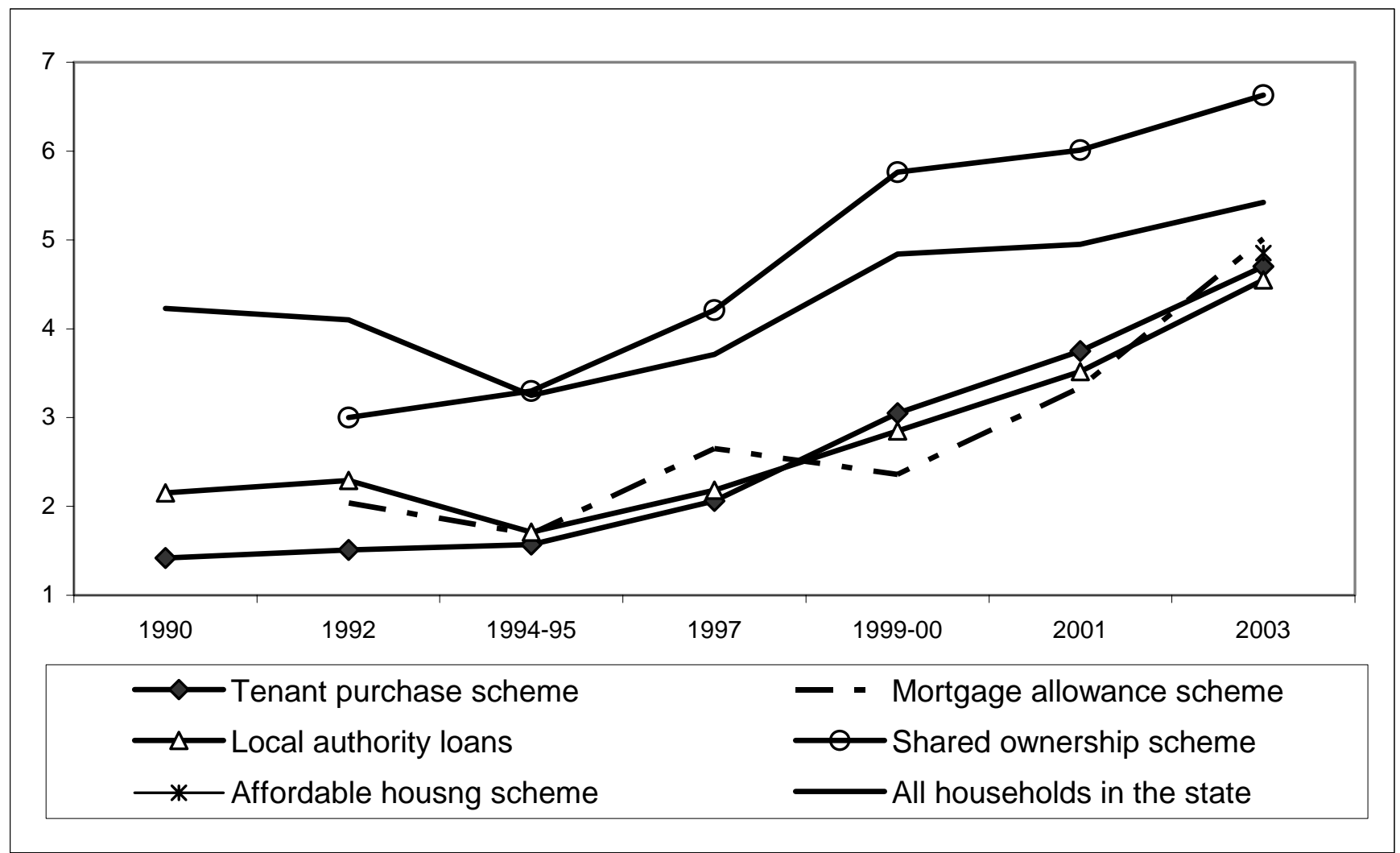

Source: Department of the Environment, Heritage and Local Government (various years) and data supplied by the Central Statistics Office.

Note: Note: data for all households is abstracted from a number of sources: 1990 and 1992 data is taken from Index of Average Industrial Earnings; 1994-95 and 1999-00 data is taken from Household Budget Survey; 1997, and 2001 data is taken form ESRI Living in Ireland Survey. 2003 data taken from the EU Survey on Income and Living Conditions 2004. Income data does not account for income tax, social insurance or pension related deductions nor does it measure welfare related inputs. Participants in the shared ownership scheme do not initially purchase all of the equity in their dwellings, in the five case study areas these households initially purchased 52 per cent of the value of their dwelling between 1991 and 2003 on average. 